\title{
Students' Strategic Thinking Ability Enhancement in Applying Scratch for Arduino of Block Programming in Computational Physics Lecture
}

\author{
Umi Pratiwi ${ }^{1, a)}$, Dwi Nanto ${ }^{2, b)}$

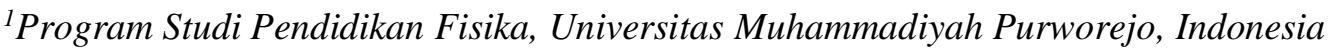 \\ ${ }^{2}$ Program Studi Tadris Fisika, Universitas Syarif Hidayatullah, Indonesia \\ $\bowtie$ : a)umipratiwi@umpwr.ac.id, b)dwi.nanto@uinjkt.ac.id
}

\begin{abstract}
As newbie programmers, university students are not accustomed to computer coding. It was difficult to solve programming problems especially related to physics phenomena. They need strategic thinking ability to solve problems. Therefore, computational physics subject/lesson applies learning of Scratch for Arduino on block programming in order to enhance students' strategic thinking. This attempt is examined by a study using a quasi-experimental method preexperimental design approach, which is one group pretest-posttest design using third-year physics education students 2018/2019 as the sample. The result shows that students happened to increase their strategic thinking up to $11.7 \%$, particularly on the ability to prove the chosen solution it is appropriate to students' problems in finishing projects categorized as "very good." It enables them to finish simple physics cases by using Arduino programming and improve their coding ability significantly.
\end{abstract}

Keywords: strategic thinking ability, block programming, scratch for Arduino

\section{INTRODUCTION}

Technology has been improving and playing an essential role in global competition. Competent human resources have been supported in this competence era. Individual competence needed recently relating to the capability of utilizing the technology of information and communication which is known better as digitalization age (Rohida, 2018). The digital industry period also known as industrial revolution 4.0, necessitates people with competences like the ones in the $21^{\text {st }}$ century in order to survive. One is able to survive when he can become proficient at information technology, media and literature information proficiency (Kalelioglu, 2014). Understanding digital technology has become obligatory in the era of industrial revolution 4.0. The period of information technology will be closed to the digitalization of technology (Grzybowska, 2017). This phenomenon will likely affect education in terms of utilizing the technology of information and communication in the teaching and learning process.

The period of digital technology offers many facilities and solutions as a means of performance enrichment employing microcontroller. The microcontroller is a series of a chip electronic or IC (Integrated circuit) that can be programmed using a computer so that it can read input, processing, and resulting output appropriately according to the purpose of program composing (Saftari, 2015). The microcontroller contains CPU (Central Processing Unit), memory, input-output certain (I/O) and supporting unit such as Analog-to-Digital Converter (ADC) integrated inside (Kadir, 2015). Arduino 
boards sold in public come with a vary of brand marks and sizes. The Arduino board used in this research is Arduino Uno (Kadir, 2016).

Arduino Uno is integrated with the program of Scratch for Arduino (S4A). S4A is a software launched from Scratch in 2017 so that it can be used for interaction with Arduino (Kadir, 2015). Scratch users are increasing so that they create their community worldwide by applying various projects including education (Resnick, 2009). In the commencing of its establishment, Scratch was intended for early education in order that early learners find it more easily to build creative thinking, collaborating and systematical programming (Resnick, 2009). Young or early programmers find some obstacles including understanding programming language syntax.

Consequently, in order to overcome that obstacle, we need easy and amusing programming like Scratch (Papadakis, 2014; Vega et al, 2014). Early or young learners learning trial using Scratch has been conducted by giving them some projects with three categories based on its function in terms of education, game and storytelling. The result of this trial shows that only $44 \%$ of learners that embrace its function while only $8 \%$ of them playing in the education category (Dahotre, 2010). The use of Scratch for education has also been tried to solve problems, dynamic learning medium, and game learning (Kordaki, 2012).

Subsequently, S4A was developed by Citilab in 2010. The purpose of making this software is to ease high school and college students in learning programming and electronics. Moreover, S4A can improve high school students' motivation and performance according to references (Ortiz-Colón, 2016). Arduino programming can be easily applied to pictorial blocks with the help of S4A. In addition, coding mistakes (writing codes) or syntax mistakes in text-based programming can be reduced for newbie programmers or those whose first time learning about programming. Arduino programming to create physics demo kits can also be applied to electronics learning other than the Computational Physics lecture. This electronic learning has become more user-friendly using S4A. The series of electronics can be controlled merely by using the program in blocks to ease the newbies (Pratiwi et al., 2018).

The development of physics learning instrument using block programming using Scratch especially S4A is highly effectively used as tools. S4A facilitates college students to increase their thinking capabilities in order to solve problems in physics learning ad physics phenomena happen in their surroundings. S4A is abundantly easy to use for newbie programmers to deepen and broaden their computational programming. The use of S4A in the learning process can help college students to think creatively and innovatively. Physics learning particularly Computational Physics, involves college students actively and necessitates them to think effectively in solving problems. Scratch learning application in physics in order to develop a physics learning medium enables to increase of students comprehensive understanding (Serevina et al., 2017). They are also accustomed to conceptualizing by identifying problems they face, the proficiency of making a decision, determining the best finishing and the ability to solve problems and evaluating them (Pratiwi, 2015). Those capabilities are strategic thinking abilities and identified as the high stage of thinking that every college student has to possess while they are mingling and interacting with their surroundings. Strategic thinking ability is needed when students finish quantum and mathematic physics (Herman, 2019). The fact shows that in 2017/2018 and 2018/2019, the score of quantum subject and subject that necessitates students' highly mathematic ability below learning target.

Moreover, strategic thinking ability is closely related to students' intelligence in combining varied intuitive abilities such as representing symbols or variables quickly and the meaning and relation of those interrelation symbols, interpreting model structure and analogy usage (Sanders, 1998; Levy, 2012). In order to improve strategic thinking ability, someone needs to have capabilities such as looking for strategic information, compiling social communication and contingency thinking sequentially (Larson dan Hansen, 2005). Ways of emerging and enhancing strategic thinking ability focused on sequentially contingency thinking ability can be conducted by computational algorithm learning (Sieg, 2007). Computational physics refers to computational coding using specific programming language sequentially and programmed in solving physics problems. Programming language learned Arduino programming language by scratch in block programming. 
This research applies to learn of block programming using S4A as the facility to increase physics students' strategic thinking ability. The learning process explores all students' capacities including affective, cognitive and psychomotor aspects to solve problems (Pratiwi, 2018).

\section{METHODS}

This research is an experimental research using a quantitative approach supported by a descriptive qualitative approach. The research design applied is quasi-experiment (Azwar, 2012) with preexperimental of Pretest-posttest one group design depicted on TABLE 1 (Arikunto, 2006, Azwar, 2012) shown in TABLE $1 . O_{1}$ a beginning test before being given treatment, $X$ refers to learning implementation of block programming using S4A (Scratch for Arduino), and $O_{2}$ is the last test after being given treatment.

TABLE 1. One Group Pre-test - Post-test design.

\begin{tabular}{lcc}
\hline Pretest & Treatment & Posttest \\
\hline$O_{1}$ & $X$ & $O_{2}$ \\
\hline
\end{tabular}

The first test done before the experiment $\left(O_{1}\right)$ is called pre-test, while the last test after the experiment $\left(\mathrm{O}_{2}\right)$ is called post-test, and the effect of treatment or experiment was done between $\left(O_{1}\right)$ and $\left(O_{2}\right)$ (Arikunto, 2002). Treatment in this research refers to the implementation of block programming using S4A. TABLE 2 shows strategic thinking ability on high order thinking (HOT) level 1.

TABLE 2. Indicators of strategic thinking ability with three stages and indicators.

HOT Level 1 Stages
Strategic Thinking

Ability

\begin{tabular}{|c|c|c|}
\hline a. & Conceptualizing & $\begin{array}{l}\text { 1. Identifying core problem variables. } \\
\text { 2. Relating problem variables. }\end{array}$ \\
\hline b. & Decision Making & $\begin{array}{l}\text { 1. Creating an estimation of an alternative approach in } \\
\text { solving problems. } \\
\text { 2. Compiling the alternative approach of problem-based } \\
\text { on appropriateness. } \\
\text { 3. Determining the best alternative suitable for the type of } \\
\text { problem. }\end{array}$ \\
\hline c. & Problem Solving & $\begin{array}{l}\text { 1. Proving or solving the chosen problem. } \\
\text { 2. Evaluating results. }\end{array}$ \\
\hline
\end{tabular}

More precise beginning tests of the research, the researcher guides college students to fill out the questionnaire in order to comprehend their beginning ability about computational programming and their understanding of Microcontroller Arduino. The first test (pre-test) is intended to know their strategic thinking ability in the first place (HOTS level 1) comprising of three stages, namely conceptualizing, decision making and problem-solving (Pratiwi dan Fasha, 2015). The first test of understanding or pre-test contains team project tasks in the portfolio and presenting the proposal. Team one first project is called "Analisis Pengukuran Suhu Cairan Dengan Kalorimeter berbasis LM35" and Team two "Eksperimentasi Hubungan Volume dan Suhu Pada Fenomena Anomali Air Berbasis Digital." Subsequently, in the final stage of post-test treatment given as project using S4A with the experiment of light-emitting diode (LED). The stage of research application is presented in FIGURE 1 as follows. 


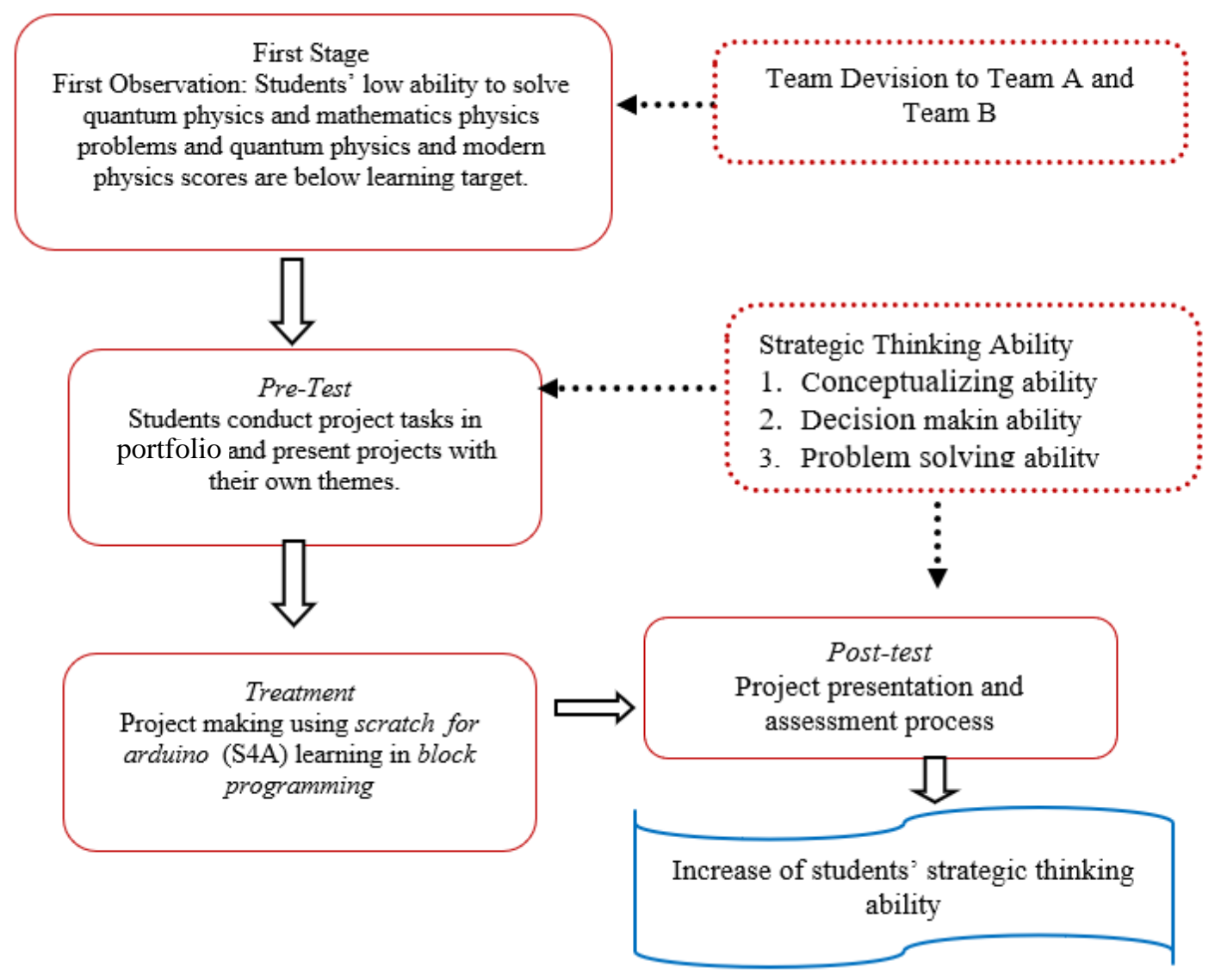

FIGURE 1. Stages of Scratch for Arduino learning application using Block Programming to enhance strategic learning ability

The three stages of strategic thinking ability consist of seven indicators of strategic thinking ability. Conceptualizing ability comprises of two indicators, decision-making ability comprises of three indicators, and problem-solving comprises of two indicators. Those detailed indicators can be seen in TABLE 2. After that, they are given the treatment of learning block programing using S4A. Applying S4A is done after knowing Arduino programming with simple projects. Successively, they try to apply S4A in terms of comprehending and learning more about the language of $C$ Arduino programming. Learning stages commences with conducting projects by each team consisting of seven students.

In the final test (post-test) students apply S4A to compare strategic thinking ability (HOTS level 1) towards the result of the pre-test. In this second stage, they are given a project to finish. Scoring of strategic thinking ability refers to Arikunto (Malik et al., 2018) is as follows.

TABLE 3. Strategic thinking ability criteria

\begin{tabular}{cc}
\hline Skor & Interpretation \\
\hline$\leq 60$ & Failed \\
$61-65$ & Less \\
$66-70$ & Enough \\
$71-75$ & Good \\
$>75$ & Very Good \\
\hline
\end{tabular}

\section{RESULTS AND DISCUSSION}

Block programming lesson using S4A is considered as learning that eases newbie programmers. Computational programming such as Arduino, integrated programming with controller software 
electronic tools. This electronics learning will be more simply using Scratch for Arduino (S4A). A series of electronics can be controlled using block programming which is easy for rookie programmers.

The result of strategic thinking ability before treatment is shown in TABLE 4 below.

TABLE 4. Result of recapitulation pre-test score of strategic thinking ability

\begin{tabular}{ccccccccc}
\hline & \multicolumn{9}{c}{ Strategic Thinking Ability (\%) } & \multirow{2}{*}{ Average } \\
\cline { 2 - 9 } Team & \multicolumn{1}{c}{ Indicator stage a } & \multicolumn{4}{c}{ Indicator stage b } & \multicolumn{2}{c}{ Indicator stage c } & \\
\cline { 2 - 9 } & $\mathbf{1}$ & $\mathbf{2}$ & $\mathbf{3}$ & $\mathbf{4}$ & $\mathbf{5}$ & $\mathbf{6}$ & $\mathbf{7}$ & \\
\hline 1 & 67,50 & 73,5 & 67,25 & 70,25 & 71,50 & 64,50 & 70,50 & 67,50 \\
2 & 65,20 & 73,00 & 65.20 & 68,20 & 69,60 & 63,40 & 71,00 & 65,20 \\
\hline Average & 66,35 & 73,25 & 67,25 & 69,22 & 70,55 & 63,95 & 70,75 & 66,35 \\
\hline
\end{tabular}

TABLE 1 above shows the result of pre-test with seven strategic thinking ability indicators, to be precise indicators 1 and 2 as the first stage, indicator 3 to 5 as the second stage, and indicators 6 and 7 as the third stage. The first indicator shows students' ability to identify problem variables. The second indicator shows the ability of connecting problem variables. The third indicator shows that students can estimate a problem-solving alternative approach. The fourth indicator shows that students can compile an alternative problem approach based on their appropriateness. The fifth indicator shows that they can determine the best alternative suitable for the core of the problem. The sixth indicator shows that they can prove or do the chosen problem-solving. Last, of all, the seventh indicator shows that they are able to evaluate the process that has been done. TABLE 1, shows the lowest score in indicator 6 . Each team pre-test score has resulted in the highest score in indicator 2, which is the ability to connect problem variables. It can be revealed from each team's explanation in exploring the ideas. The lowest score in indicator 6 , which refers to the ability to prove or do the chosen problem-solving. This ability is shown by students' inability to make a series of similar ideas written by excluding PIN Arduino which is supposedly done (on the red circle). On the other hand, team 1 has a higher score than that of team 2. Project scheme for team 1 and team 2 illustrated in FIGURE 2.

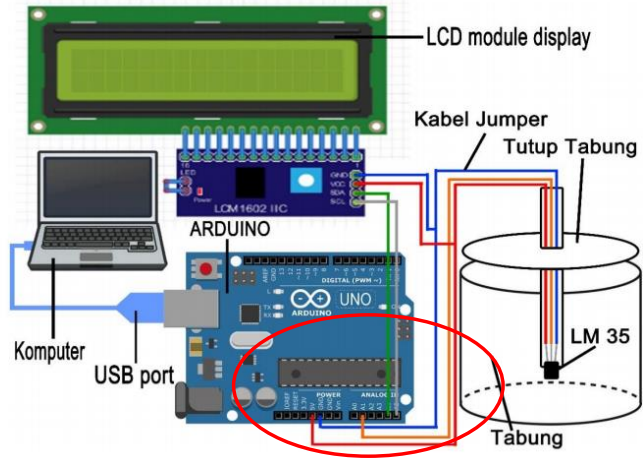

Team 1

\section{Skema Alat Pengukur Anomali Air}

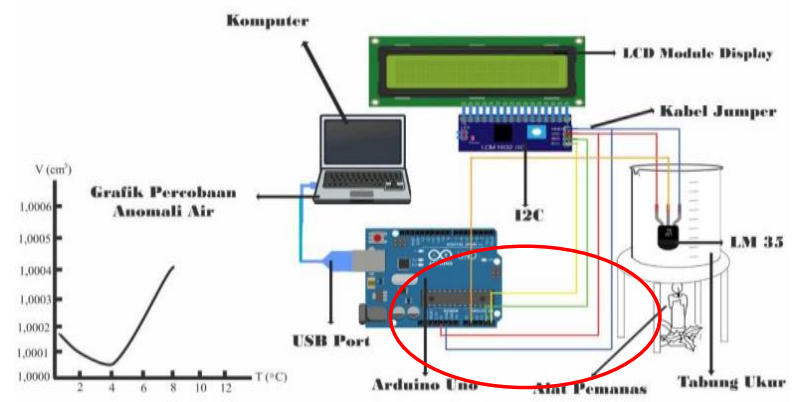

Team 2

FIGURE 2. Team 1 and Team 2 pre-test project representation.

The students, generally, still have the low capability to represent solutions or formula suitable to the problem. The highest score in the fifth indicator is the ability to determine the best alternative suitable to the problem.

In the second stage, they are given a project that has to be done in a team. The project groups are divided into two teams with different themes consisting of seven students. Each team has to finish and analyze using Arduino programming without making tools. The first theme is about water anomaly in fluids and the second theme is about measuring temperature in the calorimeter. Each team makes a proposal for finishing their themes. The final score of strategic thinking ability is depicted in the following TABLE 5 . 
TABLE 5. Result of post-test recapitulation score in strategic thinking ability

\begin{tabular}{|c|c|c|c|c|c|c|c|c|}
\hline \multirow{3}{*}{ Team } & \multicolumn{7}{|c|}{ Strategic Thinking Ability (\%) } & \multirow[t]{3}{*}{ Average } \\
\hline & \multicolumn{2}{|c|}{ Indicator stage a } & \multicolumn{3}{|c|}{ Indicator stage $b$} & \multicolumn{2}{|c|}{ Indicator stage c } & \\
\hline & 1 & 2 & 3 & 4 & 5 & 6 & 7 & \\
\hline 1 & 77,00 & 78,00 & 77,00 & 75,00 & 76,5 & 76,5 & 65,00 & 75,00 \\
\hline 2 & 65,00 & 63,00 & 77,00 & 77,5 & 77,00 & 78,00 & 75,00 & 73,21 \\
\hline Average & 71,00 & 70,50 & 77,00 & 76,25 & 76,75 & 77,25 & 70,00 & 74,11 \\
\hline
\end{tabular}

Graphic of scoring correlation before and after the learning is shown in the following picture.

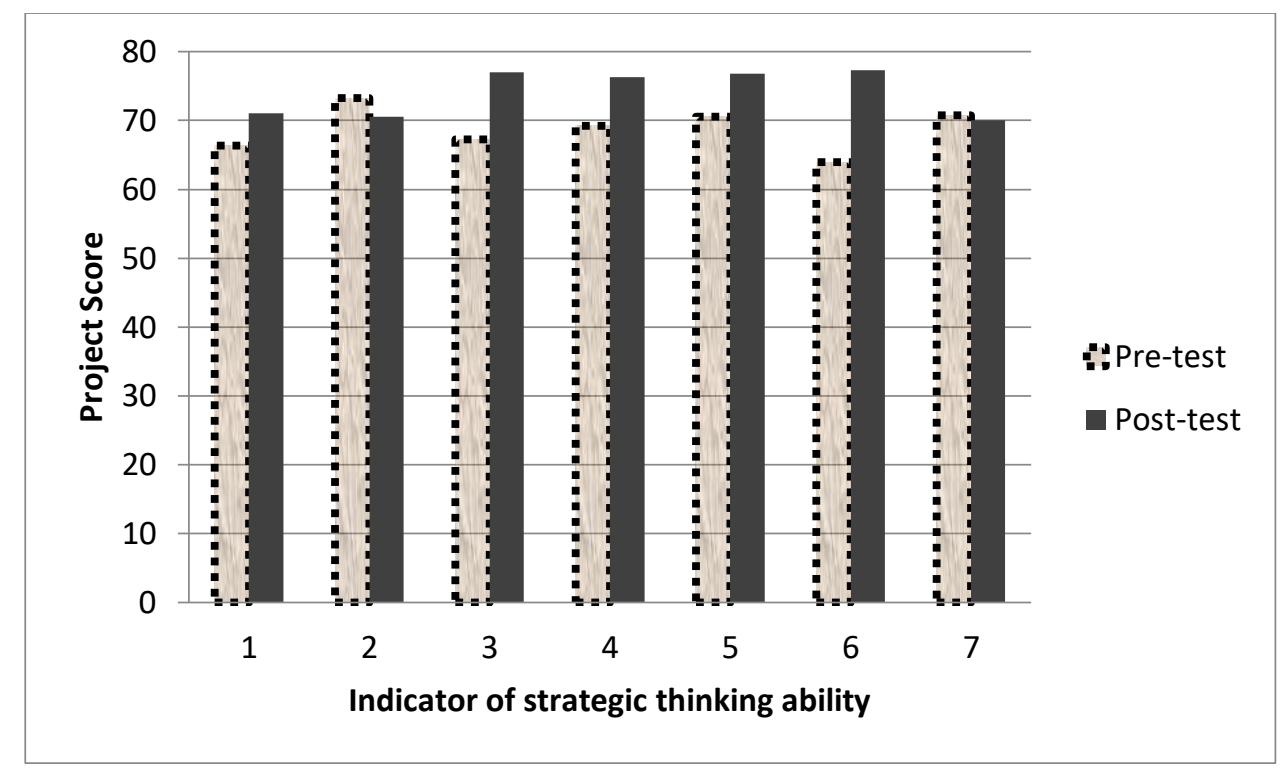

FIGURE 3. Graphic of post-test and pre-test score.

FIGURE 3 shows the result of the project score in strategic thinking ability before and after learning for seven indicators. The indicator with the significant increase is in the sixth indicator which refers to a student who can make the chosen solution representation.

FIGURE 4 is the project task with an experiment LED that shows the second indicator ability in decision making. Both teams show their distinctive abilities in representing solutions in block programing and connecting problem variables. Team 1 and Team 2 show the ability to represent the solution that they have chosen. 


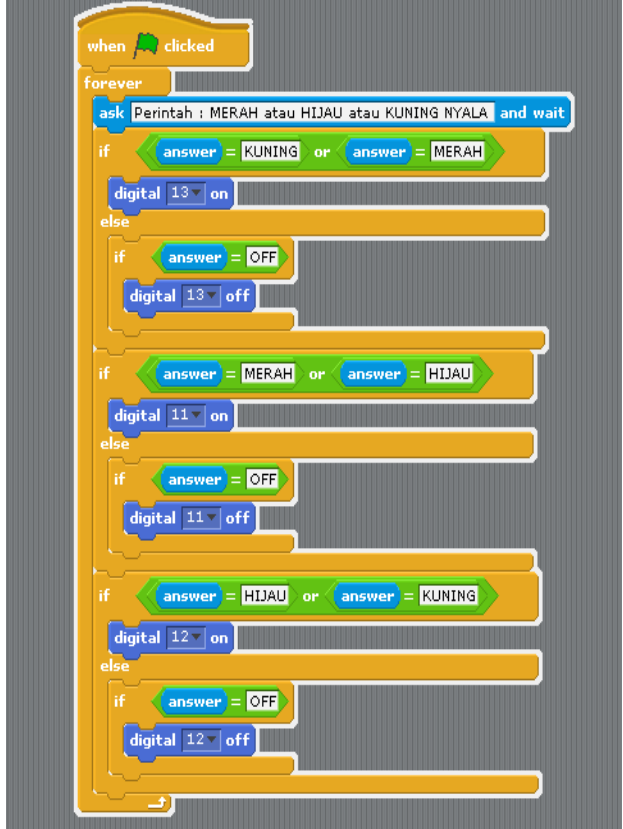

Team 1

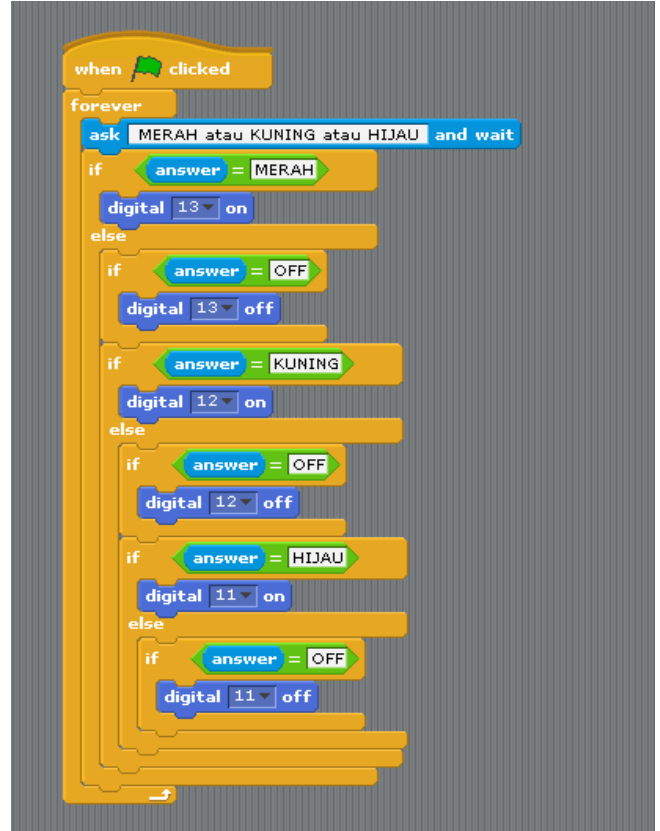

Team 2

FIGURE 4. Representation of students' strategic thinking ability in the level of decision making in finishing the same project.

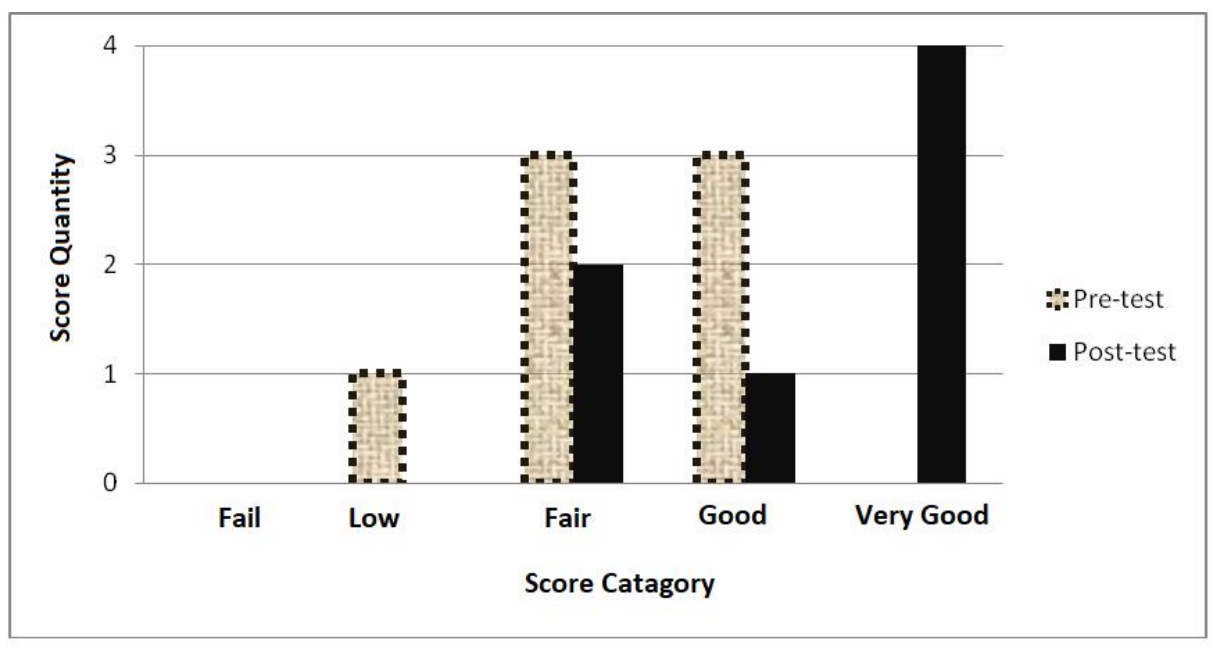

FIGURE 5. Graphic of category score of strategic thinking ability.

FIGURE 5 indicates students' strategic thinking ability. Before learning how to implement S4A, the lowest score in the Low category is $10 \%$ and the highest category Good is $30 \%$. After learning S4A, their scores increase with the lowest score category Enough and the highest score is Very Good is $40 \%$. It describes that the difficulty average dealt with by the students is in the level of problemsolving. This stage shows the ability to prove problems in the algorithm in Arduino programming language which then represented again using S4A in the language of block programming. Furthermore, there is a significant obstacle that refers to students' ability to connect problem variables and represented in the form of S4A.

The result of scratch learning by block programming shows students' representing ability in compiling or Arduino programming code building is easier and direct. Back then, students only used regular flow chart model in order to build Arduino programming codes as physics teaching aids. However, as a result of learning scratch block programming, students find it easier to make code programming to solve problems. 
As a whole, the implementation of block programming S4A learning has succeeded in increasing strategic thinking ability with $11,7 \%$. Students become accustomed to making the program of Arduino coding that represented again in S4A. By implementing block programming, they are expected to be able to finish other more complicated and complex projects.

\section{SUMMARY}

Students' strategic thinking ability has been enhanced by implementing Scratch for Arduino (S4A) in block programming in the Computational Physics lecture. This effort results in the increase of students' strategic thinking with an $11.7 \%$ increase. The highest increase happens in the level of problem-solving, precisely in the ability to represent proving solutions to a problem. Before the Computational Physics lecture, their implementation of S4A was in the score category of Good. On the other hand, after this lecture implements S4A, it reaches the category score of Very Good. Before students knew about scratch, they solved problems only by drawing a design of tools without first analysis and appropriate solutions. After the treatment, the students find it easier to finish physics projects using scratch block programming with program stages and in phases compared to conditions before treatment. Stages of S4A simplifying Arduino programming seem to be important and beneficial in learning students' strategic thinking ability in Computational Physics lecture particularly.

\section{REFERENCES}

Arikunto, S., 2006. Prosedur Penelitian. Yogyakarta: Rineka Cipta.

Azwar, S., 2012. Metode Penelitian. Yogyakarta: Pustaka Pelajar.

Dahotre, A. Z. Y. a. S. C 2010. A qualitative study of animation programming in the wild. Proceedings of the 2010 ACM-IEEE International Symposium on Empirical Software Engineering and Measurement.

Grzybowska, K. a. Ł. A., 2017. Key competencies for Industry 4.0. Economics \& Management Innovations, vol. 1, no. 1, pp. 250-253.

Herman, T 2019. Capability of mathematical strategic thinking through quantum learning based on creative problem solving. Journal of Physics: Conference Series, vol. 1320, no. 1, p. 012099.

Kadir, A., 2015. Buku Pintar Pemrograman Arduino: Tutorial Mudah dan Praktis Membuat Perangkat Elektronik Berbasis Arduino. Yogyakarta: Andi .

Kadir, A., 2016. Scratch for Arduino Panduan untuk Mempelajari Elektronika dan Pemrograman. Yogyakarta: Andi.

Kalelioglu, F. a. G. Y., 2014. The Effects of Teaching Programming via Scratch on Problem Solving Skills: A Discussion from Learners Perspective. Informatics in Education, vol. 13, no. 1, pp. 33-50.

Kordaki, M., 2012. Diverse Categories of Programming Learning Activities could be Performed within Scratch. Procedia-Social and Behaviour Scirnces, vol. 46, pp. 1162-1166.

Levy, A. (2012). STRATEGIC THINKING AS A LEARNING PROCESS. Revista Científica" Visión de Futuro, vol. 16, no. 1.

Larson, R., \& Hansen, D 2005. The development of strategic thinking: Learning to impact human systems in a youth activism program. Human Development, vol. 48, no. 6, pp. 327-349.

Malik, A. V. a. C. M. M., 2018. Improving Students' Critical-Thinking Skills Through Student Facilitator and Explaining Modelin Momentum and Impulse Topic. Jurnal Penelitian dan Pengembangan Pendidikan Fisika, vol. 4, no. 2, pp. 55-64.

Ortiz-Colón, A. d. M. R. J., 2016. Teaching with Scratch in Compulsory Secondary Education. iJET, vol. 11 , no. 2 , pp. 60-67. 
Papadakis, S. K. M. O. V. a. Z. N., 2014. Novice programming environments. Scratch \& app inventor: A first comparison.. Proceedings of the 2014 workshop on interaction design in educational environments, p. 1.

Pratiwi, U. d. F. E., 2015. Pengembangan Instrumen Penilaian HOTS Berbasis Kurikulum 2013 Terhadap Sikap Disiplin. Jurnal Penelitian dan Pembelajaran IPA, vol. 1, no. 1, pp. 123-142.

Pratiwi, U. S. d. A. R., 2018. Student Computational Logical Thinking of Block Programming Concept in Arduino Learning By S4A (Scratch for Arduino). ASSEHR AECON, vol 267, pp. 245-248.

Resnick, d., 2009. Scratch: Programming for all communications of the acm,. communications of the acm, vol. 52, no. 11 , pp. 60-67.

Rohida, L., 2018. Pengaruh Era Revolusi Industri 4.0 terhadap Kompetensi Sumber Daya Manusia. Jurnal Manajemen Bisnis Indonesia, vol. 6, no. 1, pp. 114-136.

Saftari, F., 2015. Proyek Robotik Keren dengan Arduino: Panduan Lengkap Memulai Proyek Robotik yang mearik.. Jakarta: Gramedia.

Sanders, T. I., \& Sanders, J. R. (1998). Strategic thinking and the new science: planning in the midst of chaos complexity and change. Simon and Schuster.

Sieg, W. (2007). The AProS project: Strategic thinking \& computational logic. Logic Journal of the IGPL, vol. 15 , no. 4 , pp. 359-368.

Serevina, V., Nasbey, H., \& Andriana, W. (2017). The Development of a learning material using the scratch programming language to helping student leaning momentum and impulse subject in senior high school. In Proceedings of international Conference on Technology and Sosial Science.

Vega, J., Murari, A., Dormido-Canto, S., Moreno, R., Pereira, A., Acero, A., \& JET-EFDA Contributors. (2014). Adaptive high learning rate probabilistic disruption predictors from scratch for the next generation of tokamaks. Nuclear Fusion, vol. 54, no. 12. 
